\title{
Peran UMKM dalam Pembangunan dan Kesejahteraan Masyarakat Kabupaten Blora
}

\section{Adnan Husada Putra ${ }^{1}$}

\begin{abstract}
According data from the Ministry of Cooperatives and Small and Medium Enterprises in 2014, there are about 57.8 million actors of MSMEs in Indonesia. In 2017 and the next few years it is estimated that the number of MSME perpetrators will continue to grow. MSMEs have an important and strategic role in national economic development. In addition to its role in economic growth and employment, MSMEs also play a role in distributing development outcomes. So far, MSME has contributed 57,60\% Gross Domestic Product (PBD) and employment rate about $97 \%$ of all national work force (MSME Business Profile by LPPI and BI 2015). SMEs have also been proven not affected by the crisis. When the crisis hit the period of 1997-1998, only MSMEs were able to remain strong. Data from the Central Bureau of Statistics shows that after the economic crisis of 1997-1998 the number of MSMEs has not decreased, it has been increasing, even absorbing 85 million to 107 million workers until 2012. In that year, the number of entrepreneurs in Indonesia is 56,539,560 units. Of this amount, Micro Small and Medium Enterprises (MSMEs) of 56,534,592 units or 99.99\%. The rest, about $0.01 \%$ or 4,968 units is a major undertaking. Examples of MSME policies of Blora district government regarding the role of MSMEs in development, especially in Blora district itself. Government at the central, provincial, to district / municipal levels are required to improve the welfare of their citizens through various efforts and innovation. To be able to achieve these goals, there are stages and processes that must be passed. So it takes seriousness with all related parties and inter-regional cooperation ties. Application of populist economy in order to realize the development and welfare of the community. The real form of the populist economy is in the form of support to micro, small and medium enterprises (MSME), so that the production of MSMEs is not only marketed in the local market but also outside the region and growing. Moreover, if supported by the use of information technology, product marketing is no longer limited by time and place.
\end{abstract}

Keywords: MSME (Micro, Small, Medium Enterprise), Development, Community Welfare.

\footnotetext{
${ }^{1}$ Program Studi Pendidikan Sosiologi Antropologi Universitas Sebelas Maret Email: adnanhusada@gmail.com
} 


\begin{abstract}
Abstrak
Berdasarkan data dari Kemenrian Koperasi dan UMKM pada tahun 2014, terdapat sekitar 57,8 juta pelaku UMKM di Indonesia pada tahun 2017 dan beberapa tahun kedepan diperkirakan bahwa jumlah pelaku UMKM akan terus bertambah. UMKM memiliki peran penting dan strategis dalam perkembangan ekonomi nasional. Sebagai tambahan dalam perannya dalam perkembangan ekonomi dan ketengakerjaan, UMKM juga berperan dalam perkembangan distribusi hasil. Sejauh ini, UMKM telah berkontribusi sebanyak 57,60\% Produk Domestik Bruto (PBD) dan mempunyai tingkat penyerapan tenaga kerja sekitar 97\% dari seluruh tenaga kerja nasional (Profil Bisnis UMKM oleh LPPI dan BI, 2015). UKM juga telah terbukti tidak terpengaruh oleh krisis. Ketika krisis yang melanda pada periode 1997-1998, hanya UMKM yang dapat kuat bertahan. Data dari Badan Pusat Statistik menunjukan bahwa setelah krisis ekonomi 1997-1998 jumlah UMKM tidak berkurang, UMKM bertambah, bahkan menyerap 85 juta hingga 107 juta pekerja hingga tahun 2012. Pada tahun itu, jumlah pengusaha di Indonesia sebanyak 56,539,560 unit. Dari jumlah ini, UMKM menduduki jumlah 56,534,592 unit atau sebanyak 99,99\%, selebihnya sekitar 0,01\% atau 4.968 unit adalah pengusaha besar. Contoh dari kebijakan UMKM di pemerintahan kabupaten Blora terkair dengan peran dari UMKM terhadap pembangunan, secara khususnya di Kabupaten Blora sendiri. Pemerintah pusat, provinsi hingga tingkat kabupaten/kotamadya diperlukan peningkatan kesejahteraan masyarakat melalui berbagai usaha dan inovasi. Untuk dapat mencapai tujuan tersebut, terdapat beberapa langkah dan proses yang harus dilewati. Sehingga dibutuhkan keseriusan seluruh pihak yang terkait dan ikatan kerjasama antar daerah. Aplikasi populisme ekonomi dalam upaya untuk merealisasikan pembangunan dan kesejahteraan dari masyarakat. Bentuk nyata dari populisme ekonomi adalah dalam bentuk dukungan kepada UMKM, sehingga produksi UMKM tidak hanya dipasarkan di pasar lokal namun juga merambah ke pasar yang lebih luas. Selain itu, jika didukung oleh penggunakan informasi teknologi, pemasaran produk tidak lagi terhambat oleh waktu dan tempat.
\end{abstract}

Kata Kunci: UMKM (Usaha Mikro, Kecil, dan Menengah), Pembangunan, Kesejahteraan Masyarakat. 


\section{PENDAHULUAN}

Perencanaan pembangunan (development planning) adalah suatu bentuk perencanaan yang berkaitan dengan upaya meningkatkan pertumbuhan tingkat ekonomi dan kesejahteraan masyarakat (Hariyono, 2010). Tidak dapat dipungkiri, Indonesia sebagai negara yang sedang berkembang tidakdapat terlepas dari kegiatan perencanaan pembangunan. Dari masa ke masa, ternyata Negara Indonesia telah mengalami perubahan paradigma dalam perencanaan pembangunan.Setidaknya sejak dimulainya era reformasi, paradigma perencanaan pembangunanberganti dari perencanaan komprehensif menjadi perencanaan strategis. Paradigma perencanaan strategis dipilih oleh pemerintah karena dirasa memiliki manfaat yang jelas dalam jangka waktu yang singkat (Hariyono, 2010). Paradigma perencanaan strategis yang dianut oleh pemerintah dalam kegiatan perencanaan pembangunan daerah memiliki nilai lebih dengan adanya pelibatan stakeholders (para pemangku kepentingan) yang menjadikan perencanaan pembangunan daerah menjadi tepat sasaran. Dengan kelebihan tersebut, makastakeholdersdapatberperan aktif dalam proses penyusunan rencana pembangunan daerah di wilayahnya masing-masing, sehingga perencanaan pembangunan daerah berlangsung secara partisipatif.

Dalam hal ini, seperti yang diamanatkan oleh UU No. 25 tahun 2004 tentang Sistem Perencanaan Pembangunan Nasional, masyarakat merupakan salah satu bagian penting dari stakeholdersyang ada. Masyarakat dilibatkan sebagai bentuk dari pemetaan lingkungan perencanaan, Denhardt (dalam Bryson, 1985) karena masyarakat-lah yang paling mengetahui bagaimana kondisi lingkungannya. Evaluasikejadian yangmenggemparkan perekonomianIndonesia dan beberapa negara di duniapada tahun 1997/1998yang mana pada saat itu usaha berskala besartidak mampu bertahan mengahadapi derasnya terpaan krisis moneter,pada waktu itu banyak perusahaan yang mengalami kebangkrutandi karenakan tidak mampu lagi memproduksi, hal itu di sebabkanoleh meningkatnya harga bahan baku yang impor, yang mana pada saatitu harga bahan baku impor mengalami kenaikan yang sangat drastis danjuga kenaikan dari sisi pajak impornya, bukan karena hal itu saja usahaberskala besar pailit, namun juga 
di sebabkan oleh meningkatnya biayacicilan utang yang di sebabkan naiknya nilai tukar rupiah terhadap dollar,selain itu sektorperbankanyang umumnya juga mengalami keterpurukansehingga menjadi permasalahan dalam hal permodalan pada usaha-usaha skala besar, lain halnya dengan UMKM pada saat itu yangcenderung bertahan, bahkan kian bertambah.

Semakin maju suatu Negara semakin banyak orang yang terdidik, dan banyak pula orang menganggur, maka semakin dirasakan pentingnya dunia wirausaha. Pembangunan akan lebih mantap jika ditunjang oleh wirausahawan karena kemampuan pemerintah sangat terbatas. Pemerintah tidak akan mampu menggarap semua aspek pembangunan karena sangat banyak membutuhkan anggaran belanja, personalia, dan pengawasannya. Oleh sebab itu, wirausaha merupakan potensi pembangunan, baik dalam jumlah maupun dalam mutu wirausaha itu sendiri. Dengan ada niat atau keinginan untuk berwirausaha akan menjadi sebuah loncatan setidaknya sebagai sebuah harapan terwujudnya pemerataan pembangunan dan kesejahteraan masyarakat. Banyak faktor psikologis yang membentuk sikap negatifmasyarakat sehingga mereka kurang berminat terhadap profesi wirausaha, antara lain sifat agresif, ekspansif, bersaing, egois, tidak jujur, kikir, sumber penghasilan tidak stabil, kurang terhormat, pekerjaan rendah, dan sebagainya. Pandangan semacam ini dianut oleh sebagian besar penduduk, sehingga mereka tidak tertarik. Tidak seperti layaknya etnis Cina yang terkenal sebagai wirausahawan yang rajin dan terampil, tetapi itu tidak menjadi sebuah patokan bahwa orang pribumi atau orang Indonesia tidak memiliki keterampilan hanya saja orang Indonesia tidak berani mengambil resiko dalam berdagang, terutama pada zaman sekarang ini zaman semakin maju kita dituntut untuk selalu kreatif dan inovatif tetapi kurang kesadaran tersebut menyebab Indonesia tertinggal dengan negara-negara dalam hal perekonomian negara.

Data dari Kementerian Koperasi dan Usaha Kecil Menengah pada tahun 2014, terdapat sekitar 57,8 juta pelaku UMKM di Indonesia. Di 2017 serta beberapa tahun ke depan diperkirakan jumlah pelaku UMKM akan terus bertambah.UMKM mempunyai peran penting dan strategis dalam pembangunan ekonomi nasional. Selain berperan dalam pertumbuhan ekonomi dan penyerapan tenaga kerja, UMKM juga berperan dalam 
mendistribusikan hasil-hasil pembangunan. Selama ini UMKM telah memberikan kontribusi pada Produk Domestik Bruto (PBD) sebesar 57$60 \%$ dan tingkat penyerapan tenaga kerja sekitar $97 \%$ dari seluruh tenaga kerja nasional (Profil Bisnis UMKM oleh LPPI dan BI tahun 2015).UMKM juga telah terbukti tidak terpengaruh terhadap krisis. Ketika krisis menerpa pada periode tahun 1997-1998, hanya UMKM yang mampu tetap berdiri kokoh. Data Badan Pusat Statistik memperlihatkan, pasca krisis ekonomi tahun 1997-1998 jumlah UMKM tidak berkurang, justru meningkat terus, bahkan mampu menyerap 85 juta hingga 107 juta tenaga kerja sampai tahun 2012. Pada tahun itu, jumlah pengusaha di Indonesia sebanyak 56.539.560 unit. Dari jumlah tersebut, Usaha Mikro Kecil dan Menengah (UMKM) sebanyak 56.534.592 unit atau 99.99\%. Sisanya, sekitar 0,01\% atau 4.968 unit adalah usaha besar.

Selama tahun 2011 sampai 2012 terjadi pertumbuhan pada UMKM serta penurunan pada usaha besar. Bila pada tahun 2011, usaha besar mencapai $41,95 \%$ tahun berikutnya hanya $40,92 \%$, turun sekitar $1,03 \%$. Pada UMKM terjadi sebaliknya. Bila usaha menengah pada tahun 2011 hanya 13,46\%, pada tahun 2012 mencapai 13,59\%. Ada peningkatan sebesar 0,13\%.Berbeda dengan usaha kecil, ada sedikit penurunan dari tahun 2011. Pada tahun itu mencapai 9,94\% namun pada tahun 2012 hanya mencapai 9,68\%, artinya menurun sekitar 0,26\%. Peningkatan cukup besar terjadi pada usaha mikro, bila tahun 2011 hanya mencapai 34,64\%, pada tahun 2012 berhasil meraih 38,81\% terjadi peningkatan sebesar 4,17\%.

Peran usaha mikro, kecil dan menengah (UMKM) dalam perekonomian Indonesia paling tidak dapat dilihat dari: (1) kedudukannya sebagai pemain utama dalam kegiatan ekonomi di berbagai sektor, (2) penyedia lapangan kerja yang terbesar, (3) pemain penting dalam pengembangan kegiatan ekonomi lokal dan pemberdayaan masyarakat, (4) pencipta pasar baru dan sumber inovasi, serta (5) sumbangannya dalam menjaga neraca pembayaran melalui kegiatan ekspor (KEMEN KUKM, 2005). Posisi penting ini sejak dilanda krisis belum semuanya berhasil dipertahankan sehingga pemulihan ekonomi belum optimal. Usaha mikro dan kecil umumnya memiliki keunggulan dalam bidang yang memanfaatkan sumberdaya alam dan padat karya, seperti: pertanian tanaman pangan, 
perkebunan, peternakan, perikanan, perdagangan dan restoran. Usaha menengah memiliki keunggulan dalam penciptaan nilai tambah di sektor hotel, keuangan, persewaan, jasa perusahaan dan kehutanan. Usaha besar memiliki keunggulan dalam industri pengolahan, listrik dan gas, komunikasi dan pertambangan. Hal ini membuktikan usaha mikro, kecil, menengah dan usaha besar di dalam praktiknya saling melengkapi. Sehingga dengan meningkatkan kinerja UMKM dengan bahan produksi lokal tanpa bergantung dengan bahan impor maka akan memperkuat pembangunan perekonomian nasional (Solikatun dan Masruroh, 2018: Saheb, dkk, 2018). Oleh karena itu pembangunan koperasi, usaha mikro, kecil dan menengah perlu menjadi prioritas utama pembangunan nasional dalam jangka panjang.

Kementerian Koperasi dan UKM telah mencanangkan 6 pendekatan utama untuk melaksanakan pembangunan koperasi dan UMKM di Indonesia, yaitu:

1. Strategi Pengembangan Lingkungan Usaha yang kondusif

Pengembangan lingkungan usaha yang kondusif bagi Koperasi dan Usaha Mikro, Kecil dan Menengah (KUMKM) dimaksudkan untuk meningkatkan daya saing KUMKM dengan menciptakan peluang usaha seluas-luasnya, menghilangkan biaya ekonomi tinggi, serta menjamin adanya mekanisme pasar yang sehat. Kebijakan pengembangan lingkungan usaha yang kondusif bagi KUMKM tidak berada pada suatu instansi tertentu, dan cenderung tersebar pada berbagai instansi.Untuk itu, koordinasi dan sinergi dengan instansi lain untuk menumbuhkan iklim berusaha yang kondusif bagi KUMKM. Pengembangan lingkungan usaha yang kondusif memerlukan adanya landasan peraturan perundang-undangan dan berbagai kebijakan pelaksanaannya yang memungkinkan KUMKM bersaing secara sehat dengan pelaku usaha lainnya. Pengembangan lingkungan usaha memiliki spektrum yang luas dan mencakup kebijakan politik, hukum, ekonomi makro, kerjasama internasional dan kebijakan pembangunan daerah, serta perijinan yang bersifat lintas sektoral. Kementerian Koperasi dan UKM akan mendorong lahirnya kebijakan dan peraturan perundang-undangan yang pro pengembangan KUMKM. 
2. Strategi Peningkatan Akses KUMKM Ke Sumberdaya Produktif

Rendahnya produktivitas KUMKM salah satunya akibat keterbatasan aksesnya kepada sumberdaya produktif. Untuk itu, pemerintah dan dunia usaha perlu mengembangkan sistem insentif agar KUMKM dapat mengakses sumberdaya produktif untuk mengembangkan usaha dan daya saingnya. Peningkatan akses KUMKM ke sumberdaya produktif ini bersifat selektif yang berfungsi sebagai stimulan bagi KUMKM dan berperan mengoreksi ketidaksempurnaan pasar sumberdaya produktif yang dihadapii KUMKM. Kementerian Koperasi dan UKM akan mendorong upaya peningkatan akses KUMKM kepada sumber-sumber permodalan dan pembiayaan, peningkatan akses pasar, akses teknologi, dan akses informasi. Mempertimbangkan jumlah KUMKM yang sangat besar, maka demi efektivitas pembangunan KUMKM ditempuh melalui pendekatan sentra disertai pengembangan pasar BDS (jasa pengembangan bisnis) di Indonesia.

3. Strategi Pengembangan Kewirausahan Dan Daya Saing KUMKM

Kewirausahaan merupakan faktor produksi terpenting untuk meningkatkan daya saing KUMKM dan daya saing ekonomi nasional. Dalam rangka mendukung pertumbuhan ekonomi yang berkelanjutan diperlukan tambahan 6 juta unit usaha baru yang berbasis pengetahuan dan teknologi selama 5 tahun mendatang. Untuk itu, Kementerian Koperasi dan UKM mengembangkan kebijakan untuk menumbuhkan wirausaha baru, mengembangkan sistem insentif untuk peningkatan kewirausahaan KUMKM yang ada, pengembangan KUMKM yang berkeunggulan kompetitif dan berbasis teknologi, serta pengembangan kebijakan produksi bersih.

4. Strategi Pemantapan Kelembagaan Koperasi Sesuai Dengan Jati Diri Koperasi

Pengembangan koperasi sejati merupakan salah satu wahana untuk mewujudkan adanya demokrasi ekonomi di Indonesia. Untuk itu, perlu upaya menyempurnakan Undang-undang Perkoperasian, meningkatkan administrasi dan pengawasan badan hukum koperasi, pemberian bimbingan dan kemudahan kepada koperasi, serta perlindungan kepada koperasi, dan perlindungan publik terhadap 
kegiatan usaha koperasi. Strategi pemantapan kelembagaan koperasi diharapkan dapat menumbuh-kembangkan 70.000 unit koperasi yang berkualitas dan mampu memberikan layanan yang baik kepada lebih dari 20 juta anggotanya.

5. Strategi Pemberdayaan Usaha Mikro

Usaha mikro merupakan kelompok pelaku usaha terbesar (96\%) di Indonesia dengan karakteristik berpenghasilan rendah, bergerak di sektor informal dan sebagian besar termasuk dalam kelompok keluarga miskin. Bahkan dalam sebagian besar kasus, kelompok usaha mikro masih belum dapat memenuhi kebutuhan dasar untuk hidup, seperti: gizi, pendidikan, kesehatan dan lain-lain. Usaha mikro memiliki karakteristik yang unik dan belum tentu dapat diberdayakan secara optimal melalui mekanisme pasar yang bersaing. Untuk itu, pemberdayaan usaha mikro perlu ditetapkan sebagai suatu strategi yang tersendiri, melalui pengembangan pranata kelembagaan usaha mikro, pengembangan lembaga keuangan mikro dan mendorong pengembangan industri pedesaan.

6. Strategi Peningkatan Sinergi Dan Partisipasi Masyarakat

Sinergi dan peran serta masyarakat dalam pembangunan ekonomi merupakan perwujudan dari demokrasi ekonomi. Strategi peningkatan sinergi dan partisipasi masyarakat dilakukan dengan pendekatan peningkatan partisipasi masyarakat dalam perencanaan, pelaksanaan dan evaluasi pembangunan KUMKM; peningkatan kapasitas institusi pembina dan dunia usaha untuk berpartisipasi dalam pembangunan KUMKM; dan pengembangan kelembagaan UMKM.

\section{METODE PENELITIAN}

Metode yang digunakan dalam penelitian ini adalah metode penelitian kualitatif dengan menggunakan pendekatan deskriptif. Penelitian deskriptif adalah penelitian yang berusaha untuk menuturkan pemecahan masalah yang ada sekarang berdasarkan data-data, jadi deskriptif ini juga menyajikan data, menganaliss dan menginterpretasi (Narbuko, 2007). Sesuai dengan 
permasalahan yang dikemukakan maka fokus penelitian ini ditekankan pada UMKM di Kabupaten Blora.

\section{HASIL DAN PEMBAHASAN}

Dalam pelaksanaan pembangunan harus ada sebuah rangsangan dari pemerintah agar masyarakat dalam keikutsertaannya memiliki motivasi. Menurut Simatupang (dalam Yuwono, 2001:124) memberikan beberapa rincian tentang partisipasi sebagai berikut :

1. Partisipasi berarti apa yang kita jalankan adalah bagian dari usaha bersama yang dijalankan bahu-membahu dengan saudara kita sebangsa dan setanah air untuk membangun masa depan bersama.

2. Partisipasi berarti pula sebagai kerja untuk mencapai tujuan bersama diantara semua warga negara yang mempunyai latar belakang kepercayaan yang beraneka ragam dalam negara pancasila kita, atau dasar hak dan kewajiban yang sama untuk memberikan sumbangan demi terbinanya masa depan yang baru dari bangsa kita.

3. Partisipasi tidak hanya berarti mengambil bagian dalam pelaksanaanpelaksanaan, perencanaan pembangunan. Partisipasi berarti memberikan sumbangan agar dalam pengertian kita mengenai pembangunan kita nilai-nilai kemanusiaan dan cita-cita mengenai keadilan sosial tetap dijunjung tinggi.

4. Partisipasi dalam pembangunan berarti mendorong ke arah pembangunan yang serasi dengan martabat manusia. Keadilan sosial dan keadilan Nasional dan yang memelihara alam sebagai lingkungan hidup manusia juga untuk generasi yang akan datang.

Hetifah (dalam Handayani 2006:39) berpendapat, "Partisipasi sebagai keterlibatan orang secara sukarela tanpa tekanan dan jauh dari pemerintah kepentingan eksternal". Menurut Histiraludin (dalam Handayani 2006:39-40) "Partisipasi lebih pada alat sehingga dimaknai partisipasi sebagai keterlibatan masyarakat secara aktif dalam keseluruhan proses kegiatan, sebagai media penumbuhan kohesifitas antar masyarakat, masyarakat dengan pemerintah juga menggalang tumbuhnya rasa memiliki dan tanggung jawab pada program yang dilakukan”. Istilah partisipasi sekarang ini menjadi kata kunci dalam setiap program pemngembangan 
masyarakat, seolah-olah menjadi "model baru" yang harus melekat pada setiap rumusan kebijakan dan proposal proyek. Dalam pengembangannya seringkali diucapkan dan ditulis berulang-ulang teteapi kurang dipraktekkan, sehingga cenderung kehilangan makna. Partisipasi sepadan dengan arti peran serta, ikut serta, keterlibatan atau proses bersama saling memahami, merencanakan, menganalisis, dan melakukan tindakan oleh sejumlah anggota masyarakat.Selanjutnya menurut Slamet (2003: 8) menyatakan bahwa, partisipasi Valderama dalam Arsito mencatat ada tiga tradisi konsep partisipasi terutama bila dikaitkan dengan pembangunan masyarakat yang demokratis yaitu :

1. Partisipasi politik (political participation)

2. Partisipasi social (sosial participation)

3. Partisipasi warga (citizen participation/ citizenship)

Dalam artikel ini saya mengambil contoh kebijakan UMKM pemerintah daerah Kabupaten Blora mengenai peran UMKM dalam pembangunan khususnya di Kabupaten Blora sendiri. Pemerintah di tingkat pusat, provinsi, hingga kabupaten/kota dituntut bisa meningkatkan kesejahteraan warganya melalui berbagai upaya dan inovasi.Untuk bisa meraih tujuan tersebut, ada tahapan dan proses yang harus dilewati. Sehingga diperlukan keseriusan bersama semua pihak terkait serta jalinan kerja sama antardaerah. Tepatnya pada tanggal 25 November 2016 Pemerintah daerah Kabupaten Blora dan Kabupaten Kudus menyepakati dan mengukuhkan Forum UMKM Kabupaten Blora oleh Bupati Kudus Musthofa selaku Pembina Forum UMKM Jawa Tengah (www.blorakab.go.id). Menurut Beliau perlu penerapan ekonomi kerakyatan guna mewujudkan pembangunan dan kesejahteraan masyarakat. Bentuk nyata dari ekonomi kerakyatan yaitu berupa dukungan kepada usaha mikro, kecil dan menengah (UMKM), sehingga hasil produksi dari UMKM tidak hanya dipasarkan di pasar lokal tetapi juga diluar daerah dan semakin berkembang. Apalagi jika didukung dengan pemanfaatan teknologi informasi, pemasaran produk tidak lagi dibatasi tempat dan waktu," kata Musthofa(www.blorakab.go.id).Musthofa yang kini masih menjabat Bupati Kudus menambahkan, kekuatan pelaku UMKM merupakan penyangga 
ekonomi kerakyatan yang sesungguhnya. Potensi yang begitu besar akan menjadi luar biasa jika potensi yang ada digerakkan dengan tepat.

"Kami (negara) telah hadir memberikan fasilitas permodalan hingga pemasaran. Melalui fasilitas kredit apa pun, silakan karena itu membantu peningkatan produktivitas usaha," paparnya. Adanya dukungan dana pinjaman seperti kredit usaha rakyat (KUR), kredit usaha produktif (KUP), Mitra 25,sudah seharusnya dimanfaatkan sebaik-baiknya oleh pelaku usaha (www.blorakab.go.id). Menurut Musthofa, program KUP awalnya merupakan hasil gagasannya dengan tujuan memberikan pinjaman usaha tanpa jaminan dan dengan bunga ringan. Selama ini pengusaha kecil kesulitan mengakses lembaga keuangan untuk mendapat bantuan modal. Dari perkataan beliau diatas bahwa pemerintah sudah memberikan fasilitas permodalan hingga pemasaran dengan berbagai dukungan dana, hal ini berarti penentu dari berjalannya program UMKM ini adalah partisipasi dari masyarakat. Partisipasi dari masyakat dan dukungan dari pemerintah dapat membuka jalan baru bagi masyarakat yang ingin berwirausaha dari mulai usaha kecil sampai menengah. Munculnya partisipasi dari masyarakat memunculkan usaha-usaha baru ataupun mengembangkan usaha yang sudah ada serta memunculkan lapangan kerja baru bagi masyarakat.

Pemerintah Blora bekerja sama dengan PKK menyelenggarakan program pelatihan secara gratis kepada pelaku UMKM dari Sampoerna dan BEDO Score Bali pada bulan April 2017. Para pelaku UMKM yang hadir berjumlah 120 orang dilatih tentang desain, pemasaran, pameran, pengembangan produk, ekspor dan pengembangan perusahaan. Sehingga diharapkan hasil UMKM daerah bisa bersaing dengan manajamen dan pengemasan lebih baik. Seperti pada pembahasan sebelumnya menurut Kementerian Koperasi dan UKM terdapat 6 pendekatan untuk mewujudkan pembangunan koperasi dan UKM di Indonesia. Pertama strategi pengembangan lingkungan usaha yang kondusif, pemerintah daerah Blora memberikan peluang kepada pelaku UMKM dengan cara pembukaan pasar baru dan relokasi/renovasi pasar lama sehingga tidak terbatas tempat dan menjamin mekanisme pasar yang sehat yang di upayakan pelaku UMKM agar dapat bersaing secara adil tanpa terdapat monopoli dari pihak tertentu. Kedua strategi peningkatan akses KUMKM ke sumber daya produktif, 
rendahnya produktifitas KUMKM salah satunya diakibatkan oleh sulitnya akses ke sumber daya produktif. Sehingga pemerintah harus memberikan inovasi kaitannya dengan sumber daya produktif. Terbatasnya akses ke sumber daya produktif bisa saja diakibatkan karena kekurangtauannya pemerintah dan pelaku KUMKM dengan potensi daerah yang dimiliki. Pemerintah harus bisa melihat potensi yang dimiliki daerah entah potensi itu sudah ada tapi belum dikenal ataupun sudah ada tapi belum dikembangkan. Selanjutnya strategi pengembangan kewirausahaan dan daya saing KUMKM dan strategi pemberdayaan usaha mikro , seperti pada bahasan diatas Pemerintah Blora menyelenggarakan program pelatihan pelaku UMKM dengan memberi pelatihan desain, pemasaran, pameran, pengembangan produk, ekspor dan pengembangan perusahaan yang diharapkan dapat memberikan keterampilan dan meningkatkan daya saing produk lokal UMKM Blora. Ini merupakan salah satu contoh peran pemerintah dan partisipasi masyarakat dalam mewujudkan pembangunan. Sehingga agar terwujudnya sebuah pembangunan yang berdasarkan kebutuhan masyarakat seharusnya dan perlu adanya partisipasi dari masyarakat serta peran pemerintah sebagai pemicu dan fasilitator dalam mewujudkan pembangunan.

\section{KESIMPULAN}

Kesimpulan yang dapat diambil dari pembahasan diatas adalah perlu penerapan ekonomi kerakyatan guna mewujudkan pembangunan dan kesejahteraan masyarakat. Bentuk nyata dari ekonomi kerakyatan yaitu berupa dukungan kepada usaha mikro, kecil dan menengah (UMKM), sehingga hasil produksi dari UMKM tidak hanya dipasarkan di pasar lokal tetapi juga diluar daerah dan semakin berkembang. Apalagi jika didukung dengan pemanfaatan teknologi informasi, pemasaran produk tidak lagi dibatasi tempat dan waktu. Serta tidak hanya dari Pemerintah saja melainkan partisipasi dari masyakat dan dukungan dari pemerintah dapat membuka jalan baru bagi masyarakat yang ingin berwirausaha dari mulai usaha kecil sampai menengah. Munculnya partisipasi dari masyarakat memunculkan usaha-usaha baru ataupun mengembangkan usaha yang sudah ada serta memunculkan lapangan kerja baru bagi masyarakat. 


\section{DAFTAR PUSTAKA}

Handayani, Sauci. (2006). Perlibatan Masyarakat Marginal Dalam Perencanaan dan Penganggaran Partisipasi. Surakata: Kompip Solo.

Hariyono. (2010). Perencanaan Pembangunan Kota dan Perubahan Paradigma. Yogjakarta: Pustaka Pelajar.

http://www.blorakab.go.id/index.php/public/berita/detail/98/pelaku-umkmblora-ikuti-score-plus-training (di akses pada tanggal 20 April 2016 Pukul 20.15 WIB).

Kementerian Koperasi dan UKM. (2005). Peran Usaha Mikro, Kecil dan Menengah Dalam Pembangunan Ekonomi Nasional. Surabaya.

Kementerian Koperasi dan UKM. Draf Rencana Strategis Pembangunan Koperasi dan UMKMPeriode Tahun 2005 - 2009. Jakarta, 2004.

LPPI, Bank Indonesia. (2015). Profil Bisnis Usaha Mikro, Kecil dan Menengah (UMKM). Jakarta.

Narbuko, C., dan Achmadi, A. 2007. Metodologi Penelitian. Jakarta: Bumi Aksara.

Saheb, S., Slamet, Y., \& Zuber, A. (2018). Peranan Modal Sosial Bagi Petani Miskin Untuk Mempertahankan Kelangsungan Hidup Rumah Tangga Di Pedesaan Ngawi (Studi Kasus Di Desa Randusongo Kecamatan Gerih Kabupaten Ngawi Provinsi Jawa Timur). Jurnal Analisa Sosiologi, 2(1).

Slamet, M. (2003). Membentuk Pola Perilaku Manusia Pembangunan. Bogor: IPB Press.

Solikatun, S., \& Masruroh, Y. (2018). Kemiskinan Dalam Pembangunan. Jurnal Analisa Sosiologi, 3(1).

Undang-undang Nomor 25 Tahun 2004 tentang Sistem Perencanaan Pembangunan Nasional.

Yuwono, Teguh. (2001). Manajemen Otonomi Daerah: Membangun Daerah Berdasar Paradigma Baru. Semarang: Clyapps Diponegoro University. 